\section{Effect of Irrigation Method on Tree Growth, Foliar Nutrient Levels, and Nut Characteristics of Young Pecan Trees in the Southern Great Plains}

\author{
Abby ShalekBriski ${ }^{1}$, B. Wade Brorsen ${ }^{1}$, Jon T. Biermacher ${ }^{2}$, \\ Charles T. Rohla ${ }^{2,3}$, and Will Chaney ${ }^{2}$
}

AdDITIONAL INDEX wORDs. Carya illinoinensis, drip irrigation, nut quality, sprinkler irrigation, tree growth, water

SuMMARY. Although irrigation is a common practice in pecan (Carya illinoinensis) orchards, the effects of different methods of irrigation on young tree growth, nut quality, and nutrient uptake have not been estimated. Five irrigation systems and one nonirrigated control system were established. Tree performance was characterized by change in trunk diameter, weight per nut, average kernel percentage, and total trunk diameter growth. Nutrient uptake was determined by foliar levels. The five irrigation systems were a microsprinkler with a $35-\mathrm{ft}$ diameter, a microsprinkler with a 70 - $\mathrm{ft}$ diameter, two subsurface driplines irrigating for 2 days/week alternating between water for 2 hours and no water for 2 hours, two subsurface driplines irrigating 1 day/week for 20 hours continuously (LI2), and four subsurface driplines irrigating for 10 hours continuously for 1 day/week (LI4). Irrigation systems affected foliar levels of potassium (K), boron (B), and manganese (Mn) levels. Irrigation system did not affect change in trunk diameter or kernel percentage. A spatial Durbin error model was estimated to use trunk diameter estimates from all trees in the orchard. This model found the trunk diameters of nonirrigated and LI4 system trees to be significantly less than those trees that were irrigated by the LI 2 system. When observations were pooled over all years, LI4 trees had individual pecan nut weights that were significantly less than all other systems.

I $\mathrm{n}$ the states of Texas and Oklahoma, it is estimated that pecans contribute more than $\$ 90$ million and $\$ 14$ million to each state's economy, respectively (Noble Research Institute, 2010). A growing interest in pecans stems from explosive growth in the export market for pecan nuts during the past several decades (Lillywhite et al., 2014). Irrigation has been found to be crucial in the establishment and growth of young nut-bearing trees in areas such as

Received for publication 17 Aug. 2018. Accepted for publication 28 Dec. 2018

Published online 15 February 2019.

The research was funded by the Noble Research Institute, Inc. B.W. Brorsen receives support from the A.J. and Susan Jacques Chair as well as the Oklahoma Agricultural Experiment Station and U.S. Department of Agriculture National Institute of Food and Agriculture, Hatch Project no. OKL02939.

${ }^{1}$ Department of Agricultural Economics, Oklahoma State University, Stillwater, OK 74078

${ }^{2}$ Noble Research Institute, LLC, Ardmore, OK 73401

${ }^{3}$ Corresponding author. E-mail: ctrohla@noble.org.

This is an open access article distributed under the CC BY-NC-ND license (https://creativecommons.org/ licenses/by-nc-nd/4.0/).

https://doi.org/10.21273/HORTTECH04162-18
Alabama (Patterson et al., 1990) and Georgia (Wells, 2017), but little is known about the relationship between irrigation and establishment in the southern Great Plains. In pecans, a recent study by Wells (2017) aimed to determine the appropriate irrigation rates and effects on growth of young pecan trees in Georgia. Wells compared two microsprinkler systems with emitters of different pressures and a nonirrigated control. During the first 2 years of the experiment, irrigated trees had greater trunk diameter growth than the nonirrigated control trees. This work agrees loosely with previous work in Alabama by Patterson et al. (1990), who compared a nonirrigated control with a drip irrigation system with five emitters per tree. No difference in trunk diameter was found during the first year between irrigated and nonirrigated trees. However, in subsequent years, Patterson et al. (1990) did find that irrigated trees had significantly larger trunk diameters.

Although some research exists on irrigation effect on the growth of young pecan trees, little to none exists on the effects of irrigation delivery system on nutrient uptake in pecan trees. Neilsen et al. (1995) investigated the effects of emitter (jet or microsprinkler) and frequency of irrigation and their effects upon 'Gala' apples (Malus $\times$ domestica). In their study, leaf concentrations of potassium $(\mathrm{K})$, magnesium $(\mathrm{Mg})$, copper $(\mathrm{Cu})$, and manganese $(\mathrm{Mn})$ were affected significantly by irrigation type and frequency. However, fertigation of nitrogen $(\mathrm{N})$ and phosphorus $(\mathrm{P}) \mathrm{oc}^{-}$ curred, potentially leaching the soil of some nutrients and consequently leading to different element leaf concentrations.

Effects of differing irrigation levels on individual pecan nut weight has been investigated previously. Garrot et al. (1993) designed four irrigation treatments based on a crop water stress index resulting in a wet, medium, and dry treatment as well as a grower-designated irrigation treatment. Sixteen trees established in 1967 were included in the 4-year experiment that started in 1988. Data pooled over the 4 years showed a decrease in pecan nut weight in relation to a decrease in water. However, the number of saleable kernels was unaffected. Although the relationship between amount of water and nut quality might be documented, there is a lack of research concerning the effects of the irrigation water delivery system and its effects upon the nut quality of young pecan trees.

Research is needed to determine the effects of irrigation water delivery method on growth, nut quality, and nutrient absorption of young pecan

\begin{tabular}{llll}
\hline $\begin{array}{l}\text { Units } \\
\text { To convert U.S. to SI, } \\
\text { multiply by }\end{array}$ & U.S. unit & SI unit & $\begin{array}{l}\text { To convert SI to U.S., } \\
\text { multiply by }\end{array}$ \\
\hline 0.3048 & $\mathrm{ft}$ & $\mathrm{m}$ & 3.2808 \\
3.7854 & gal & $\mathrm{L}$ & 0.2642 \\
2.54 & inch(es) & $\mathrm{cm}$ & 0.3937 \\
25.4 & inch $(\mathrm{es})$ & $\mathrm{mm}$ & 0.0394 \\
1 & $\mathrm{mmho} / \mathrm{cm}$ & $\mathrm{dS} \cdot \mathrm{m}^{-1}$ & 1 \\
28.3495 & $\mathrm{oz}$ & $\mathrm{g}$ & 0.0353 \\
1 & $\mathrm{ppm}$ & $\mathrm{mg} \cdot \mathrm{kg}^{-1}$ & 1
\end{tabular}


trees. The objectives of our study were to determine the effects of different types of drip and sprinkler irrigation systems, and the periodicity of irrigation as well as a nonirrigated control on the change in trunk diameter, kernel percentage, pecan nut weight, and leaf element concentrations.

\section{Materials and methods}

In 2007, 'Pawnee' pecan trees were planted at the Noble Research Institute's McMillan Research and Demonstration Farm near Madill, OK (lat. $34^{\circ} 2^{\prime} 10.4238^{\prime \prime} \mathrm{N}$, long. $96^{\circ} 56^{\prime} 27.0378^{\prime \prime} \mathrm{W}$; elevation, 236 $\mathrm{m})$. The trees on 'Apache' rootstock were planted at a spacing of $35 \times 35 \mathrm{ft}$ on Bastrop fine sandy loam soil. The soil was well drained, with a depth to the water table of more than 80 inches. The infiltration rate was moderately high to high (0.60-2.00 inches $/ \mathrm{h}$ ). The available water storage in the profile is high (about 10 inches). 'Kanza' pollinator rows were located on the south, middle, and north end of the study block. Trap counts were used to monitor pecan nut casebearer (Acrobasis nuxvorella) and pecan weevil (Curculio caryae). Visual inspection was used to determine when control for aphids [blackmargined pecan aphid (Monellia caryella) and yellow pecan aphid (Monelliopsis pecanis)] was necessary. Based on trap counts, foliar chemical sprays were applied by air-blast sprayer to control for pecan nut casebearer and pecan weevil. Pecan scab (Fusicladium effusum) was not present in this orchard. Glyphosate application was applied across the orchard floor to maintain 14 -ft-wide vegetation-free strips down the orchard rows. Vegetation outside of the orchard was mowed twice per year with a batwing mower. Trees received fertilizer annually according to annual leaf sample recommendations based on the work of Smith et al. (2012) to provide sufficient nutrients.

Table 1 reports an average rainfall of $966.987 \mathrm{~mm}$ at the Madill Mesonet station (Mesonet 2018), which is also located on the McMillian Research and Demonstration Farm. Annual rainfall decreased to less than the 15-year average for $2011,2012,2013,2014,2016$, and 2017. In 2015, more than double the amount of rainfall occurred in comparison with the 15-year average.

Treatments. Irrigation systems were installed and trees began receiving water in 2008. The study began in 2010. At the beginning of the study, the irrigation water quality was analyzed (Table 2 ). The reported sodium absorption ratio, electrical conductivity, nitrate, sulfate, and chloride levels are within suitable levels as deemed by Zhang (2017). Treatments were five different irrigation systems and one nonirrigated system (Table 3 ). The systems consisted of a microsprinkler with 35-ft diameter ( $\mathrm{R}-5$ rotator; Nelson, Walla Walla, WA), a microsprinkler with a $70-\mathrm{ft}$ diameter $(\mathrm{R}-10$ rotator, Nelson), two subsurface driplines on a short-interval watering system $(2 \mathrm{~h}$ on $/ 2 \mathrm{~h}$ off system $)$ for $2 \mathrm{~d} /$ week, two subsurface driplines irrigating with a continuous run for $20 \mathrm{~h} \mathrm{l} \mathrm{d} /$ week, and four subsurface driplines irrigating with a continuous run for $10 \mathrm{~h} \mathrm{l}$ d/week. Sprinkler systems (R5 and R10) had one emitter per tree located $4.5 \mathrm{ft}$ east in the herbicide strip. To ensure that sprinkler systems did not wet the leaves, the branches were pruned. However, overlap of wetting patterns did occur in the Rl0 system and could possibly influence the growth of neighboring trees. Subsurface drip irrigation systems with two driplines (SI2 and LI2) were located $7 \mathrm{ft}$ from the trunk of the tree on two opposite sides, buried 14 inches deep. The driplines for the LI4 system were also placed on two opposite sides of a tree, $7 \mathrm{ft}$ from the trunk of the tree and buried 14 inches deep. All subsurface dripline systems used pressure-compensating inline emitters (Netafim USA, Fresno, CA) at 0.9 $\mathrm{gal} / \mathrm{h}$ spaced $4 \mathrm{ft}$ apart. All irrigated systems delivered the same amount of water per week $(2.16 \mathrm{~cm})$ per the recommendations of local producers. Irrigation began at budbreak in the middle of April through the summer months. The full irrigation schedule ran each week regardless of precipitation received. Irrigation was shut off 2 weeks before harvest. Each system was replicated three times in a completely randomized design. A treatment block consisted of 12 trees in which the middle two trees were sampled and the surrounding 10 trees acted as a border to negate effects for neighboring treatment blocks. A block was arranged by three rows and four columns of trees.

Data collection. Collection of leaf samples occurred each year in July. Leaf samples were collected to ensure proper management of nutrients and elements within the orchard

Table 1. Monthly rainfall at the Madill Mesonet station near Madill, OK, in 2010-17.

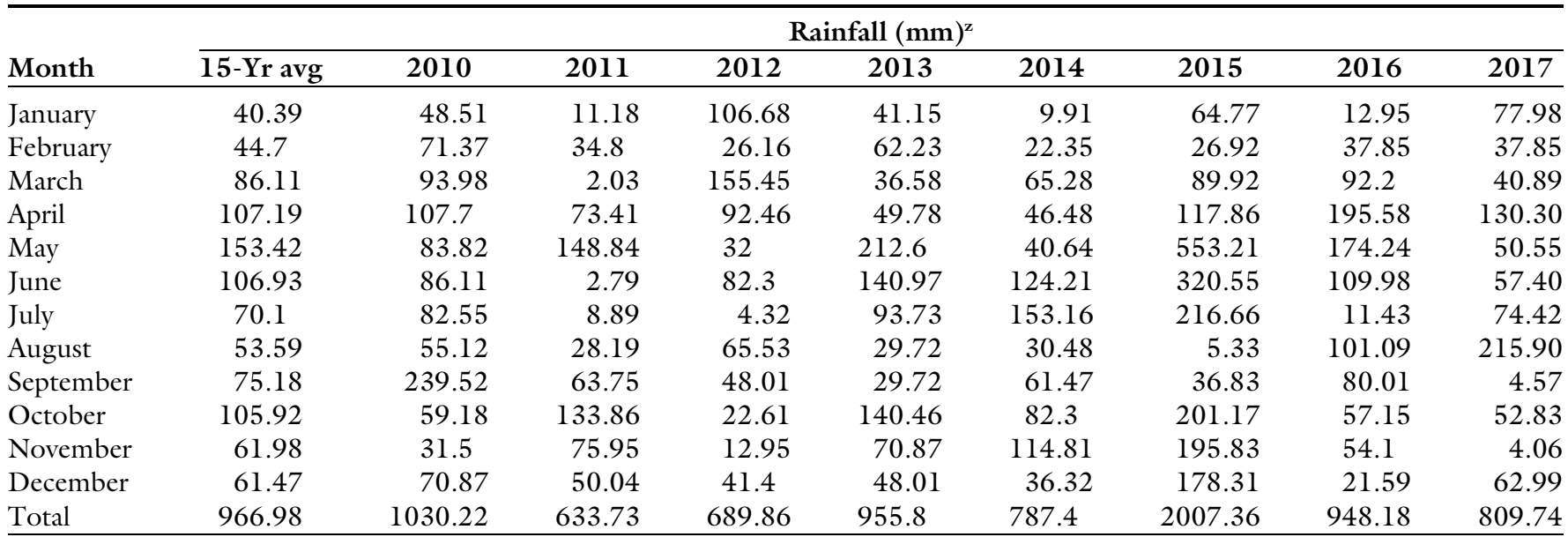

${ }^{\mathrm{z}} 1 \mathrm{~mm}=0.0394$ inch. 
as well as to determine whether irrigation had any effect on nutrient and element absorption. One hundred leaflets were collected per tree at random from the middle leaf. Leaves were washed in deionized water, then washed in deionized water with nondetergent soap, and then rinsed in deionized water. The leaves were dried before being analyzed by the Oklahoma State University Soil, Water and Forage Analytical Laboratory. Total $\mathrm{N}$ and carbon (C) were determined using a dry combustion $\mathrm{C} / \mathrm{N}$ analyzer (LECO Corp., St. Joseph, MI) (National Forage Testing Association, 1993). Mineral contents of the plant samples were analyzed by an inductively coupled plasma spectrometer (Arcos; SPECTRO Analytical

Instruments, Kleve, Germany) after acid digestion (Undersander et al., 1993).

Elemental concentrations of $\mathrm{N}$, calcium (Ca), K, Mg, nickel (Ni), B, $\mathrm{Mn}, \mathrm{P}$, iron (Fe), $\mathrm{Cu}$, sulfur (S), and zinc $(\mathrm{Zn})$ were collected during 2013, 2014, 2015, and 2016. Change in trunk diameter ( $1.4 \mathrm{~m}$ above the soil) was measured using calipers during dormancy, annually during 2010, 2011, 2013, and 2015. Total trunk diameter was measured for all 215 trees in the orchard in Jan. 2018. Trees were harvested annually, with a 40-nut sample after $90 \%$ split shuck. Nuts were placed on drying racks in a room with unheated air and dried to $4 \%$ to $5 \%$ moisture. The 40-nut sample was evaluated each year for kernel percentage and weight per nut. One pecan tree in the treatment

Table 2. Irrigation water quality measurements from McMillian Research and Demonstration Farm near Madill, OK.

\begin{tabular}{lc}
\hline Parameters & Irrigation water, Madill, OK \\
\hline Sodium absorption rate & 1.4 \\
$\begin{array}{l}\text { Electrical conductivity } \\
(\mathrm{mmho} / \mathrm{cm})^{\mathrm{z}}\end{array}$ & 0.93 \\
Nitrate $(\mathrm{ppm})^{\mathrm{z}}$ & 0.1 \\
Chloride $(\mathrm{ppm})$ & 26 \\
Boron $(\mathrm{ppm})$ & 0.13 \\
\hline
\end{tabular}

${ }^{\mathrm{z}} 1 \mathrm{mmho} / \mathrm{cm}=1 \mathrm{dS} \cdot \mathrm{m}^{-1}, \mathrm{l} \mathrm{ppm}=1 \mathrm{mg} \cdot \mathrm{kg}^{-1}$.

Table 3. Abbreviation definitions for irrigation system treatments from McMillian Research and Demonstration Farm near Madill, OK.

\begin{tabular}{ll}
\hline Abbreviation & \multicolumn{1}{c}{ Irrigation system $^{\mathrm{z}}$} \\
\hline None & No irrigation \\
$\mathrm{R} 5$ & Microsprinkler with a 35-ft diameter \\
$\mathrm{R} 10$ & Microsprinkler with a 70-ft diameter \\
$\mathrm{S} 22$ & Subsurface drip with two lines (short watering interval) \\
$\mathrm{LI} 2$ & Subsurface drip with two lines (long watering interval) \\
LI4 & Subsurface drip with four lines (long watering interval) \\
${ }^{{ }^{\mathrm{L}} 1 \mathrm{ft}=0.3048 \mathrm{~m} .}$ &
\end{tabular}

that received no irrigation died and was removed from the study in 2013.

Data analysis. Measures of elemental concentration were subjected to analysis of variance models using a mixed-effect model with repeated measures, in which irrigation systems were treated as fixed effects and year was treated as a random effect using the MIXED procedure in SAS (version 9.2; SAS Institute, Cary, NC) (Little et al., 1996) The relationship between irrigation systems and the change in tree diameter was fitted to a log linear model with repeated measures using the MIXED procedure in SAS, in which irrigation system was treated as a fixed effect and year was treated as a fixed effect. Means were separated using the LSMEANS statement in SAS $(P \leq$ $0.05)$. The relationship between nut kernel percentage and irrigation system as well as the relationship between nut weight and irrigation system were modeled using the NLMIXED Procedure in SAS (Wolfinger, 1999), in which irrigation system and year were treated as fixed effects and the interaction between the irrigation system, replication, and year was treated as a random effect. Heteroskedasticity occurred within the sample because some pecan trees had less than 40 nuts available to sample. A correction for heteroskedasticity was made, as suggested by Richter and Brorsen (2006). Means were separated using the CONTRAST statement in SAS $(P \leq 0.05)$.

In Jan. 2018, trunk caliper measurements were taken of all 215 trees in the orchard. Previous analysis of the caliper measurements, nut weight, and kernel percentage was done for the 36

Table 4. Mean leaf element concentrations in 'Pawnee' pecans and sufficiency standards for 2013-16.

\begin{tabular}{|c|c|c|c|c|c|c|c|c|c|c|c|c|}
\hline \multirow[b]{2}{*}{ Irrigation system $^{\mathrm{z}}$} & \multicolumn{6}{|c|}{ Elemental concn (\%) } & \multicolumn{6}{|c|}{ Elemental concn (ppm) } \\
\hline & $\mathbf{N}$ & $\mathbf{P}$ & $\mathbf{K}$ & $S$ & $\mathrm{Ca}$ & $\mathrm{Mg}$ & B & $\mathrm{Cu}$ & $\mathrm{Fe}$ & Mn & $\mathrm{Zn}$ & $\mathrm{Ni}$ \\
\hline None & 2.34 & 0.12 & $0.83 \mathrm{bcd}^{y}$ & 0.2 & 1.58 & 0.4 & $52.6 \mathrm{c}$ & 7.8 & 46.9 & $1,324.64 \mathrm{a}$ & 28.25 & 4.43 \\
\hline $\mathrm{R} 10$ & 2.31 & 0.12 & $0.8 \mathrm{~cd}$ & 0.2 & 1.7 & 0.44 & $70.41 \mathrm{a}$ & 7.8 & 49.1 & $909.54 \mathrm{~b}$ & 26.77 & 3.73 \\
\hline SI2 & 2.32 & 0.1 & $0.89 \mathrm{abc}$ & 0.2 & 1.69 & 0.4 & 59.05 bc & 7.6 & 50.7 & $1,091.69 \mathrm{ab}$ & 28.78 & 3.65 \\
\hline LI2 & 2.29 & 0.1 & $0.93 \mathrm{a}$ & 0.2 & 1.7 & 0.39 & $68.07 \mathrm{a}$ & 8 & 49.5 & $1,087.14 \mathrm{ab}$ & 29.27 & 3.76 \\
\hline Sufficiency $^{x}$ & $2.3-3.0$ & $\geq 0.14$ & $\geq 1.0$ & $\geq 0.20$ & $\geq 0.70$ & $\geq 0.30$ & $15-300$ & $6-20$ & $\geq 50$ & $\geq 100$ & $\geq 60$ & $\geq 2.5$ \\
\hline
\end{tabular}

${ }^{\mathrm{z}}$ Treatments are defined in Table 1

${ }^{y}$ Means in the same column followed by the same letter are not significantly different using Fisher's protected least significant difference at $P \leq 0.05$.

${ }^{\mathrm{x}}$ Smith et al. (2012).

Ns, *Nonsignificant or significant at $P \leq 0.05$, respectively.

$\mathrm{N}=$ nitrogen $; \mathrm{P}=$ phosphorus $\mathrm{K}=$ potassium $; \mathrm{S}=$ sulfur; $\mathrm{Ca}=$ calcium $; \mathrm{Mg}=$ magnesium $; \mathrm{B}=$ boron; $\mathrm{Cu}=\mathrm{copper} ; \mathrm{Fe}=$ iron $; \mathrm{Mn}=$ manganese $\mathrm{Zn}=\mathrm{zinc} ; \mathrm{Ni}=$ nickel . $\mathrm{lppm}=1 \mathrm{mg} \cdot \mathrm{kg}^{-1}$. 
Table 5. Relationship of irrigation system to change in trunk diameter, weight per nut, and kernel percentage of 'Pawnee' pecans.

\begin{tabular}{|c|c|c|c|c|c|c|c|c|}
\hline Irrigation system $^{z}$ & 2010 & 2011 & 2012 & 2013 & 2014 & 2015 & 2016 & Pooled \\
\hline \multicolumn{9}{|c|}{ Change in trunk diam $(\mathrm{cm})^{\mathrm{y}}$} \\
\hline None & 3.98 & 4.63 & - & 7.58 & - & 8.68 & - & 5.82 \\
\hline $\mathrm{R} 5$ & 4.62 & 5.04 & - & 9.33 & - & 9.64 & - & 6.75 \\
\hline $\mathrm{R} 10$ & 5.52 & 5.87 & - & 9.19 & - & 9.58 & - & 7.32 \\
\hline SI2 & 3.56 & 4.16 & - & 8.32 & - & 9.63 & - & 5.92 \\
\hline LI2 & 4.76 & 5.27 & - & 9.21 & - & 9.52 & - & 6.80 \\
\hline \multicolumn{9}{|l|}{ Weight $(\mathrm{g} / \text { nut })^{\mathrm{x}}$} \\
\hline None & - & - & $7.79 a b^{w}$ & - & $9.88 \mathrm{a}$ & 9.64 & 9.24 & $9.18 \mathrm{a}$ \\
\hline R5 & - & - & $9.53 \mathrm{ab}$ & - & $10.07 \mathrm{a}$ & 9.20 & 8.66 & $8.73 \mathrm{a}$ \\
\hline Rl0 & - & - & $9.5 \mathrm{ab}$ & - & $8.75 \mathrm{~b}$ & 9.83 & 8.83 & $9.86 \mathrm{a}$ \\
\hline $\mathrm{SI} 2$ & - & - & 8.79 b & - & $10.13 \mathrm{a}$ & 9.57 & 8.91 & $9.34 \mathrm{a}$ \\
\hline $\mathrm{LI} 2$ & - & - & $10.36 \mathrm{a}$ & - & 8.64 b & 9.71 & 8.89 & $8.79 \mathrm{a}$ \\
\hline None & - & - & 52.23 & - & $56.06 \mathrm{a}$ & 57.3 & 57.51 & 57.36 \\
\hline $\mathrm{R} 5$ & - & - & 47.22 & - & $52.38 \mathrm{a}$ & 55.96 & 56.78 & 55.59 \\
\hline Rl0 & - & - & 50.23 & - & $44.54 \mathrm{~b}$ & 56.9 & 56.51 & 54.25 \\
\hline SI2 & - & - & 52.63 & - & $55.96 \mathrm{a}$ & 57.71 & 56.93 & 57.17 \\
\hline LI2 & - & - & 49.39 & - & $45.35 \mathrm{~b}$ & 56 & 56.47 & 54.11 \\
\hline $\mathrm{LI} 4$ & - & - & 45.89 & - & $52.15 \mathrm{a}$ & 52.59 & 54.38 & 55.04 \\
\hline Significance & - & - & NS & - & * & NS & NS & NS \\
\hline
\end{tabular}

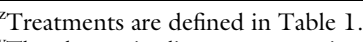

${ }^{\mathrm{y}}$ The change in diameter was estimated using a log linear function, and therefore the expected change in trunk diameter has been adjusted by $\frac{\sigma^{2}}{2} .1 \mathrm{~cm}=0.3937$ inch.

${ }^{\mathrm{x}} \mathrm{lg}=0.0353 \mathrm{oz}$

${ }^{\text {w}}$ Means in the same column followed by the same letter are not significantly different using Fisher's protected least significant difference at $P \leq 0.05$.

Ns, *Nonsignificant and significant at $P \leq 0.05$, respectively.

trees located in the center of the 12 -tree treatment blocks. Little statistical significance was found as a result of the small sample size. To address this issue, a larger sample size was obtained by measuring the diameter of all trees in the orchard.

When all the trees in the orchard were sampled, the border effects needed to be considered. The model used controlled for potential spillover effects from bordering trees of a different treatment, specifically the effect of a nonirrigated tree bordering a tree receiving irrigation. Using exploratory spatial data analysis, which takes into account the existence of spatial autocorrelation and its effects on the assumption of independence (Anselin, 1999), a spatial weight matrix was specified that reflected whether a nonirrigated tree bordered an irrigated tree. With the weight matrix specification, a spatial Durbin error model was found to be the most appropriate model to explain the data.

\section{Results and discussion}

The leaf elemental concentrations (Table 3 ) of $\mathrm{N}, \mathrm{S}, \mathrm{Ca}, \mathrm{Mg}, \mathrm{B}$,
$\mathrm{Cu}, \mathrm{Fe}, \mathrm{Mn}$, and $\mathrm{Ni}$ were all within the guidelines set by Smith et al. (2012) for a high-input cultivar orchard (Table 3). K, P, and Zn levels were below elemental sufficiency ranges. Leaf element concentrations for $\mathrm{K}, \mathrm{B}$, and $\mathrm{Mn}$ displayed statistical differences in levels by irrigation system when pooled over the years. Levels of $\mathrm{K}$ showed no clear pattern. The LI2 system displayed the greatest levels of $\mathrm{K}$ whereas the LI4 had the least leaf concentrations of $\mathrm{K}$. This could possibly be the result of the number of emitters. Four emitters could be more detrimental to leaf concentration of $\mathrm{K}$ in comparison with two emitters; however, we cannot fully explain why the number of emitters could be detrimental to the concentration of $\mathrm{K}$ in the leaf samples. The statistical difference in B levels was the least for the control system with no irrigation (None) and greatest in the sprinkler systems (R5 and RI0) as well as the LI2 system. Besides the nonirrigated trees, the SI2 and LI4 systems had no statistical difference in concentration of $\mathrm{B}$, and, on average,
Table 6. Spatial Durbin error model estimates of the effect of irrigation treatment on pecan trunk diameters in Jan. 2018.

\begin{tabular}{lc}
\hline $\begin{array}{l}\text { Irrigation } \\
\text { system }^{\mathrm{z}}\end{array}$ & Trunk diam $(\mathrm{cm})^{\mathrm{y}}$ \\
\hline None & $134.49 \mathrm{c}^{\mathrm{x}}$ \\
R5 & $155.59 \mathrm{ac}$ \\
R10 & $152.2 \mathrm{abc}$ \\
SI2 & $151.6 \mathrm{abc}$ \\
LI2 & $162.79 \mathrm{a}$ \\
LI4 & $145.71 \mathrm{bc}$ \\
Significance & $*$ \\
\hline
\end{tabular}

${ }^{{ }^{2}}$ Treatments are defined in Table 1

${ }^{\mathrm{y}} \mathrm{l} \mathrm{cm}=0.3937$ inch.

${ }^{\mathrm{x}}$ Means in the same column followed by the same letter are not significantly different using Fisher's protected least significant difference at $P \leq 0.05$.

*Significant at $P \leq 0.05$.

had some of the lowest leaf concentrations. This occurrence may be a result of the length of time water is applied. The SI2 and LI4 systems apply water for the longest total periods of time throughout the week. However, this explanation does not give insight into why the nonirrigated systems have the least amount of $\mathrm{B}$ on average. Mn concentrations were the least for the 
two sprinkler systems (R5 and Rl0) and greatest for the no irrigation control (None). Because the LI4 system Mn leaf concentration is significantly greater than with both sprinkler systems, perhaps a greater number of emitters that created a highly concentrated dispersion of water increased Mn solubility, and thus availability to the trees.

During the 7 years of our study, rainfall was inconsistent from April to September. The years 2011, 2012, and 2013 were dry; the rainfall totals for those months were less than the 15-year average. Although no evapotranspiration or mid-stem water potential data are available, it should be noted that particularly dry years could have led to water stress on the trees. It is interesting to note that there seems to be no difference between the irrigated system and the nonirrigated system during the dry years. Perhaps this is a result of the maintenance of the herbicide strips around the tree, decreasing the trees' competition for water.

As the trees grew, the average change in diameter increased each year (Table 4). Although there was no statistically difference in change of diameter, numerically-on average-both sprinkler irrigation systems (R5 and Rl0) as well as the LI2 system experienced a greater increase in trunk diameter in contrast to the other three irrigation systems. The lack of significant effect of irrigation on trunk diameter contradicts recent findings by Wells (2017). Wells (2017) began acquiring measurements immediately upon planting of the trees, whereas our study had 2 years postplanting when no records were kept. But, it could also be that using only the two center trees led to our test having a low statistical power.

Individual nut weights were recorded in 2012, 2014, 2015, and 2016 (Table 5). In 2014, the nonirrigated control, R5, and SI 2 systems had significantly greater individual nut weights than the RI0 and LI2 systems. When observations were pooled across years, nut weights from the LI4 irrigation system were significantly less than the other systems.

Kernel percentage was significantly less in the R10 and LI2 systems during 2014. When pooled across years, no significant difference in kernel percentage was found between systems.

Using data on all trees and correcting for edge effects, the effect of irrigation on trunk diameter was significantly different for LI2 relative to the nonirrigated and LI4 system (Table 6). The LI2 and R5 systems were the only irrigation systems to have significantly greater trunk diameters than the nonirrigated control.

These responses to irrigation method varied from year to year with weather and other variables. In some years, for certain measures of growth and maturity, the nonirrigated control outperformed irrigated systems. In measures for change in trunk diameter, there was no difference between any system when using only the two center trees of each plot. When all 215 trees in the orchard were sampled and spatial effects were accounted for, the LI2 and R10 systems had significantly greater trunk diameters than the nonirrigated control. The trunk diameter of the LI2 irrigation system trees was also significantly greater than those of the LI4 trees when spatial effects were accounted for Kernel percentage of nuts was unaffected by irrigation system when pooled over all years. The individual pecan nut weight was significantly less for nuts from the LI4 irrigation system trees in comparison with the rest of the irrigation treatments. With respect to the individual nut weight and trunk diameter, the LI4 system can be generally characterized as the worst system, having significantly lower individual nut weights than even the nonirrigated control. The LI4 irrigation system also had the least levels of foliar $\mathrm{K}$.

In our study, the nonirrigated control differed significantly only from the majority of the irrigated systems for total trunk diameter in the spatial Durbin error model. However, the findings of our study should be extrapolated to other pecan-growing regions of the country with caution. Statistical insignificance does not mean that the effect of irrigation is truly zero. In this instance, the effect of irrigation might be small in comparison with the variation within the observations. Also, irrigation may affect trees more greatly in regions where little rainfall occurs or, conversely, may have less of an effect where greater rainfall is experienced.

\section{Literature cited}

Anselin, L. 1999. Interactive techniques and exploratory spatial data analysis, p. 251-264. In: P.A. Longley, M.F. Goodchild, D.J. Maguire, and D.W. Rhind (eds.). Geographical information systems: Principles, techniques, management and applications. Wiley, New York, NY.

Garrot, D.J., M.W. Kilby, D.D. Fangmeier, S.H. Husman, and A.E. Ralowicz. 1993. Production, growth, and nut quality in pecans under water stress based on the crop water stress index. J. Amer. Soc. Hort. Sci. 118:694-698.

Lillywhite, J.M., J.E. Simonsen, and R.J. Heerema. 2014. US consumer purchases and nutritional knowledge of pecans. HortTechnology 24:222-230.

Little, R.C., G.A. Miliken, W.W. Stroup, and R.D. Wolfinger. 1996. SAS system for mixed models. SAS Inst., Cary, NC.

Mesonet. 2018. Mesonet rainfall by month table, Madill, OK. 30 Jan. 2018. <https://wwww.mesonet.org/index. php/weather/monthly_rainfall_table>.

National Forage Testing Association. 1993. Forage analyses procedures. $\mathrm{Na}-$ tional Forage Testing Assn., Omaha, NE.

Neilsen, G.H., P. Parchomchuk, D. Neilsen, R. Berard, and E.J. Hague. 1995. Leaf nutrition and soil nutrients are affected by irrigation frequency and method for NPfertigated 'Gala' apple. J. Amer. Soc. Hort. Sci. 120:971-976.

Noble Research Institute. 2010. Noble Research Institute's pecan research strategy. 19 June 2018. <https://www.noble. org/news/publications/ag-news-andviews $/ 2010 /$ october / noble foundations-pecan-research-strategy $/>$.

Patterson, M.G., G. Wehtje, and W.D. Goff. 1990. Effects of weed control and irrigation on the growth of young pecans. Weed Technol. 4:892-894.

Richter, F.G.-C. and B.W. Brorsen. 2006. Aggregate versus disaggregate data in measuring school quality. J. Prod. Anal. 25:279-289.

Smith, M.W., C.T. Rohla, and W.D. Goff. 2012. Pecan leaf elemental sufficiency ranges and fertilizer recommendations. HortTechnology 22:594-599.

Undersander, D., D.R. Mertens, and N. Thiex. 1993. Forage analyses. National Forage Testing Assn., Omaha, NE.

Wells, L. 2017. Response of young pecan trees to irrigation in a humid climate. HortScience 53:457-462.

Wolfinger, R.D. 1999. Fitting nonlinear mixed models with the new NLMIXED procedure. Proc. 24th Annu. SAS Users Group Intl. Conf. p. 278-284.

Zhang, H. 2017. Classification of irrigation water quality. Oklahoma Coop. Ext. Serv. PSS-2401. 